\title{
Categorisation and Relevance of Policing Models in the Literature ${ }^{1}$
}

\section{Barbara HARMATI ${ }^{2}$}

This article presents a review of keywords available in the literature focusing on policing models, with the aim of evaluating how authors and KeyWords Plus classify these models. The literature shows that even though several policing models have been published since the 1970s, there is no common categorisation of the different approaches. This, however, would help unifying the area. A strong relationship between third-party policing, problem-oriented policing, community policing, evidence-based policing, and hot spot policing models was also identified, meaning that usually two or more of these approaches were used in conjunction. The analysis of the keywords showed that three main policing models exist today: community policing, predictive policing and evidence-based policing.

Keywords: policing models, community policing, evidence-based policing, predictive policing

\section{Introduction}

In the 1960s, both police and community were facing numerous issues. For example, within the police, the dominant model worldwide was the traditional policing model, which is based on random patrol, rapid response, intensive enforcement, arrest policies and investigations of criminal activities; all these led to the need of increasing the size of police agencies. ${ }^{3}$ As the crime rate began to rise in the 1960 s, it showed that police methods within this framework were not effective in reducing criminal activities. This loss of effectiveness led to the loss of police legitimacy and citizens' trust. ${ }^{4}$ During this time, the officers' social status remained low, despite the efforts to professionalise policing. ${ }^{5}$

1 The author would like to thank the Evidence-Based Policing Centre (New Zealand), especially Clara Cantal, PhD, Senior Research Insights Advisor for sharing her knowledge and expertise.

2 Barbara Harmati, PhD student, University of Public Service, Doctoral School of Law Enforcement. E-mail: harmatib@ gmail.com

3 David Weisburd and John E Eck, 'What Can Police Do to Reduce Crime, Disorder, and Fear?', The Annals of the American Academy of Political and Social Science 593, no 1 (2004), 40.

4 George L Kelling and Mark Harrison Moore, 'From Political to Reform to Community: The Evolving Strategy of Police', in Community Policing: Rhetoric or Reality, ed. by Jack R Greene and Stephen D Mastrofski (Westport: Praeger Publishers, 1988), 1-23.

5 Jack R Greene (ed.), Encyclopedia of Police Science (London: Routledge, 2012), 211-212; Jerome H Skolnick and David H Bayley, The New Blue Line: Police Innovation in Six American Cities (New York: Simon and Schuster, 1988). 
Within the communities around the world, as social disorder and the crime rate increased, the fear of crime also increased drastically. The occurrence of social disorder and the lack of confidence in public policing led to the rise in the use of private security and the rise of the community crime control movement. The era of proactive policing arose from the previously mentioned social processes and the negative critique to traditional practices. ${ }^{6}$

Since the 1970s, numerous policing models have been published and changed the way of thinking about policing. However, the literature shows that the models published have not been categorised under a common framework, which makes it difficult to compare them. In order to evaluate how authors and KeyWords Plus classify the models presented in the policing literature, this article evaluates keywords on articles published between 1960 and 2018 based on the synonyms described by Bruinsma and Weisburd (2014) in the Encyclopedia of Criminology and Criminal Justice. ${ }^{7}$

\section{Method}

The Encyclopedia of Criminology and Criminal Justice contains the most current policing models and related synonyms. The policing model and these synonyms (see Table 1) were used to search for research articles published between January of 1960 and December of 2018 in the Web of Science database. This timeframe was chosen to make sure all the relevant articles were considered and to evaluate when policing models first appeared in the literature after the collapse of the traditional model in the 1960s.

In this review of literature, keywords generated by the authors and available in the articles, also keywords generated by KeyWords Plus were evaluated as the main aim of this study was to understand how authors perceive and categorise policing models presented in their articles. This measure (i.e. evaluation of keywords) can also be used as a proxy measure of what types of models have been published. Thus, research articles were collected based on policing models and related synonyms published by Bruinsma and Weisburd (2014) ${ }^{8}$ and analysed based on their keywords to understand how policing models have been acknowledged and related in the scientific literature.

The article's title, keywords, publication date and number of times the article was cited were recorded in an SPSS database for each research article found using the search terms. The title was the unique key used to distinguish articles. There were two types of keywords associated to research articles - the ones noted by the authors

\footnotetext{
Gerben Bruinsma and David Weisburd (eds), Encyclopedia of Criminology and Criminal Justice (New York: Springer, 2014).

Ibid.

8 Ibid.
} 
on the research article and the ones generated automatically by KeyWords Plus. ${ }^{9}$ As this tool also considers words or phrases on the reference list of the article, keywords generated by it also show how the article relates to articles cited in it. In this sense, keywords generated by KeyWords Plus capture the content of the article in greater depth and variety than the usual keywords produced by authors. ${ }^{10}$

In this article, keywords produced by authors were used to investigate how policing models are categorised by the authors and the keywords produced by KeyWords Plus were used to understand how each policing model relates to other models in the literature. The publication date was used to evaluate trends on policing models. The number of times the article was cited was not analysed in this paper.

Table 1 presents the frequency and percentage of articles found per search term. A larger frequency of articles related to community policing, problem-oriented policing, intelligence-led policing, predictive policing and evidence-based policing was found (see Table 1). Less than 1 per cent of the articles was found using the synonym reassurance policing. Further analyses are not presented for articles found using this search term given the small frequency of articles.

Table 1: Articles found in the literature per synonym published by Bruinsma and Weisburd (2014)

\begin{tabular}{|c|c|c|}
\hline Policing model-terms & $\begin{array}{l}\text { Number of } \\
\text { records }\end{array}$ & Percentage \\
\hline Community policing, community-oriented policing & 801 & 61.57 \\
\hline Problem-oriented policing, problem-solving policing & 112 & 8.61 \\
\hline Intelligence-led policing, information-led policing & 93 & 7.15 \\
\hline Predictive policing & 86 & 6.61 \\
\hline Evidence-based policing & 66 & 5.07 \\
\hline "Broken windows" policing, order maintenance policing & 65 & 5.00 \\
\hline Zero tolerance policing & 26 & 2.00 \\
\hline Third-party policing & 24 & 1.84 \\
\hline Hot-spot policing, place-based policing & 19 & 1.46 \\
\hline Reassurance policing & 9 & 0.69 \\
\hline
\end{tabular}

\section{Results and discussion}

Results are presented in three different sections: 1. trends within policing models; 2. policing models according to keywords used by author; and 3. policing models according to keywords generated by KeyWords Plus.

Keywords from KeyWords Plus are based on the title of the research article and on words or phrases on the reference list (Clarivate.com, 'KeyWords Plus Generation, Creation, and Changes', 2019).

10 Eugene Garfield, 'KeyWords PIus: 1S1's Breakthrough Retrieval Method. Part 1', Current Contents 32 (1990), 3-7. 


\section{Trends within policing models}

The first proactive policing models which appeared in the field after the collapse of the traditional model were community and problem-oriented policing. The basic rule of community policing is to build a bridge between community and police. It calls for a need to redefine the role of police and the decentralisation of police services along with the hierarchy. The most important outcome of the model is a greater reciprocity between community and police. ${ }^{11}$ This outcome aims to eventually create a less bureaucratic, specialised and hierarchical police structure.

According to Goldstein (1990), problem-oriented policing aims to provide better methodologies for addressing crime and disorder problems. "Whereas communityoriented policing provided a broader vision of the police role in society, problem solving provided a set of 'tools' to work with in that broader context."12

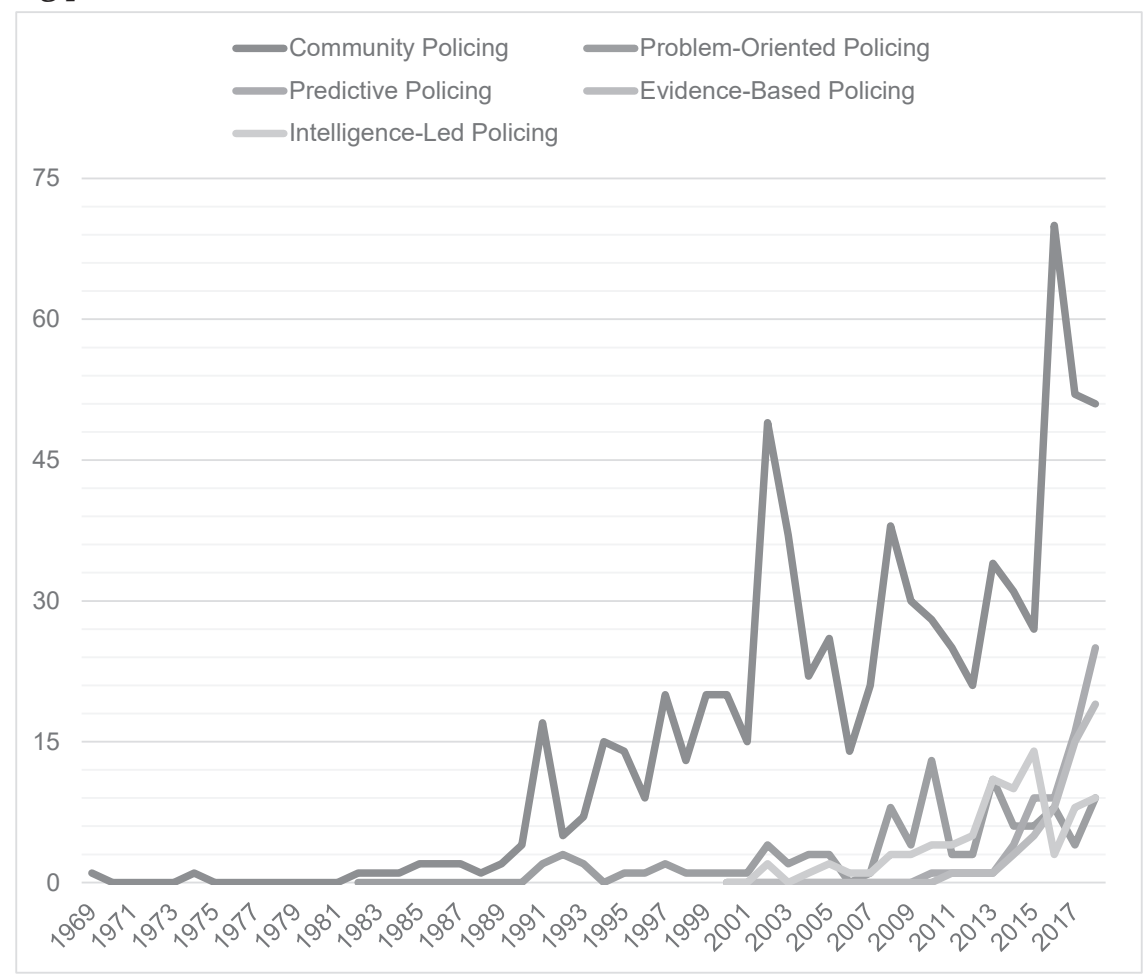

Figure 1: Policing models and the number of publications per year.

Source: KeyWord Plus

11 Skolnick and Bayley, The New Blue Line: Police Innovation in Six American Cities.
12 Greene, Encyclopedia of Police Science, 978-979. 
These two policing models were not the only new models developed as a reaction to the failure of the traditional, reactive policing model. After the 9/11 terrorist attack, more strategic policing approaches appeared, eventually leading to the intelligence-led policing model. The hot spot policing model was created as a part of problem-oriented policing, with other techniques also designed to apply patrol resources and energy in a more focused way. ${ }^{13}$

Figure 1 shows the number of publications for each policing model per year. Community policing appeared in the United States around the 1970s in the wake of the dissatisfaction with the traditional policing model. ${ }^{14}$ The production of articles under this framework started to increase in 1981, fluctuated between 1990 and 2001, increased again in 2002 and decreased again until the biggest spike so far in 2016. Thus, community policing is still relevant in the field.

Problem-oriented policing was introduced to the field in $1990 .{ }^{15}$ The presence and the use of this model only increased after 2008. Before that, only a few articles had been published.

Other policing models like intelligence-led policing, evidence-based policing and predictive policing only appeared after 2000. The presence of intelligence-led policing increased after 2001, ${ }^{16}$ making it the second main policing model referred between 2011 and 2015, just after community policing (see Figure 1). Evidence-based policing was first mentioned in a conference in 1998 by Sherman, ${ }^{17}$ and predictive policing in 2008 by Bratton, ${ }^{18}$ but these models started to be referred to more frequently in the literature just after 2013. Figure 1 shows when specific types of policing models first appeared in the literature and when they started to be more frequently referred in the literature. The figure shows that an increase in the frequency in which models were referred tended to occur generally after more than 15 years after they were first referred in the literature.

After 2016, predictive policing became the second, and evidence-based policing the third main policing model published, just after community policing model (see Figure 1).

\section{Policing models according to keywords used by author}

This section presents results based on the keywords provided by authors on the research articles, providing insight about how authors define and categorise the models presented in their papers.

\footnotetext{
Ibid. 1020.

Bruinsma and Weisburd, Encyclopedia of Criminology and Criminal Justice, 418.

Herman Goldstein, Problem-Oriented Policing (New York: McGraw-Hill Ryerson, 1990).

Greene, Encyclopedia of Police Science, 685.

Lawrence W Sherman, Evidence-Based Policing (Washington, D.C.: Police Foundation, 1998).

18 William Bratton, 'Transcript: Perspectives in Law Enforcement - The Concept of Predictive Policing: An Interview with Chief William Bratton'. Interview by Jim Burch and Kris Rose (Bureau of Justice Assistance, 2008).
} 


\section{Community policing}

Bayley \& Shearing (1996) described community policing as a new organising paradigm, a revolution in police work, or even a new orthodoxy. ${ }^{19}$ Brogden \& Nijhar (2005) called it a buzzword that comes in all shapes and sizes. ${ }^{20}$ Overall, the literature shows that it is very difficult to find or establish a common definition of community policing, as techniques come from a multitude of policing models and best practices are not concise. Community policing is rather a general organisational strategy of police work ${ }^{21}$. Trojanowicz \& Bucqueroux (1990) defined community policing as a philosophy and organisational strategy, which focuses on the relationship between community members and police to work together in order to solve problems of crime, physical disorder, social disorder and neighbourhood decay. ${ }^{22}$ It requires a preventive approach with the promotion of citizens' involvement. ${ }^{23}$

The keywords defined by authors show that community policing has a relationship with problem-oriented policing (10 per cent of the publications about community policing contain problem-oriented policing as keyword). These models seem to be different, however, keywords connected to the models do not always appear in conjunction.

Skogan and Harnett (1999) identified five central elements to community policing: 1. decentralisation of organisation; 2. two-way communication between the police and the public; 3 . responsiveness to citizens' needs; 4 . commitment to help community to solve their problems on their own; and 5. implementation of problemoriented policing strategies. ${ }^{24}$ Skogan and Frydl (2004) noted that community policing can have a great impact on reducing crime if it is supplemented with hot spot policing and problem-oriented policing. ${ }^{25}$ Community policing can be effective in combination with problem-oriented policing, but it is a model in its own right. According to Tilley (2003) the relevance of problem-oriented policing in not limited to community policing. Within problem-oriented policing, the relationship between police and community is functional, with members of the community being "eyes and ears" of officers. ${ }^{26}$

\footnotetext{
David H Bayley and Clifford Shearing, 'The Future of Policing', Law and Society Review 30, no 3 (1996), 585-606.

20 Michael Brogden and Preeti Nijhar, Community Policing: National and International Models and Approaches (Cullompton: Willan Publishing, 2005).

21 Bruinsma and Weisburd, Encyclopedia of Criminology and Criminal Justice, 417.

22 Robert C Trojanowicz and Bonnie Bucqueroux, Community Policing: A Contemporary Perspective (Cincinnati: Anderson Publishing Company, 1990).

23 Bruinsma and Weisburd, Encyclopedia of Criminology and Criminal Justice, 417.

24 Wesley G Skogan and Susan M Hartnett, Community Policing, Chicago Style (Oxford: Oxford University Press, 1999).

25 Wesley G Skogan and Kathleen Frydl, Fairness and Effectiveness in Policing: The Evidence (Washington, D.C.: The National Academies Press, 2004).

26 Nick Tilley, 'Modern Approaches to Policing: Community, Problem-Oriented and Intelligence-Led', in Handbook of Policing, ed. by Tim Newburn, $1^{\text {st }}$ ed. (Cullompton: Willan Publishing, 2003), 373-403.
} 
In the past decades, community policing became a dominant policing model. Consequently, new subtypes appeared - broken windows policing, zero-tolerance policing and third-party policing.

The broken windows policing, or order maintenance policing and zero-tolerance policing are based on Wilson and Kelling's (1982) broken windows theory. Broken windows policing focusses on solving minor offences and neighbourhood disturbances in order to address problems in the community. ${ }^{27}$ This approach can also be viewed within the problem-oriented policing framework but is more related to community policing. In New York and Chicago during the 1990s, significant crime reduction was credited to the broken windows approach. ${ }^{28}$

Broken windows policing is often mistakenly mixed with zero-tolerance policing. Within this model, police issue citations and arrest people who violate the law with little or zero consideration of the circumstances surrounding the event. It was implemented first in New York in 1994, following the broken windows theory principle that if any social or physical disorder is left unattended, it will eventually cause serious crime in the community. ${ }^{29}$ Zero-tolerance policing can be viewed as a form of community policing, but merely as an aggressive version of it.

Keywords by authors show that the publications about community policing contain broken windows policing as keywords less than 5 per cent of the articles. The number of keywords by authors relating to community policing and zero-tolerance policing is smaller, less than 2 per cent. The author's keyword analysis did not confirm a strong relationship between community policing with broken windows policing and zero-tolerance policing. This finding might suggest that broken windows policing and zero-tolerance policing should not be considered within the framework of community policing.

Third-party policing, according to Buerger and Mazerolle (1998), involves formal, noncriminal controls imported from the regulatory wing of civil law. ${ }^{30}$ In the model, the third-party is an intermediate class of non-offending persons who is thought to have some power over the offender's primary environment. In this context, a third-party could manipulate the environment in a way to frighten away or impose noncriminal penalties to people who behave in a deviant manner. Keywords by authors show that third-party policing do not relate to community policing.

\footnotetext{
George L Kelling and James Q Wilson, 'Broken Windows', Atlantic Monthly 249, no 3 (1982), 29-38.

Bruinsma and Weisburd, Encyclopedia of Criminology and Criminal Justice, 3349-3350.

Richard A Wright and J Mitchell Miller (eds), Encyclopedia of Criminology (New York: Routledge, 2005), 930.

Michael E Buerger and Lorraine Green Mazerolle, 'Third-Party Policing: A Theoretical Analysis of an Emerging Trend', Justice Quarterly 15, no 2 (1998), 301-327.
} 


\section{Problem-oriented policing}

According to Goldstein $(1979,1990)$, police needs to be more efficient and effective in reducing criminal activities. As a result, police officers need to collect information about events and design an appropriate response based on the nature of the underlying conditions which cause criminal problem(s) by detailing its conduct and analysing systematically incidents and underlying factors. Goldstein (1979) felt that police must go further than answering call after call and searching for solutions to recurring problems that generate the repeated calls. He called this strategy a "problem-oriented approach" and envisioned it as a department-wide activity. ${ }^{31}$

Problem-oriented policing contains a set of different tools, but the most known are the problem analysis triangle (PAT) and the scanning, analysis, response and assessment (SARA) model. ${ }^{32}$ Scanning refers to the identification of an issue and determining whether it is a problem, which involves the identification of problems that are worth to analyse. Analysis refers to the data collection to understand the scope, nature and causes of the problem. Response is the action based on the evidence obtained following analysis and may involve other agencies. Assessment refers to an evaluation of the results in order to re-examine the problem and change responses or maintain positive conditions. ${ }^{33}$

Community policing can be effective in combination with problem-oriented policing, and also have a significant impact on reducing criminal activities. ${ }^{34}$ As shown in the previous section, keywords by author showed that in 10 per cent of the publications community policing appeared in conjunction with problem-oriented policing.

Hot spot policing can be viewed as a subtype of problem-oriented policing, as it appears related to problem-oriented policing in almost 15 per cent of the publications. Hot spot is a specific geographic area that is smaller than the units that police departments typically use. ${ }^{35}$ It can be viewed as a micro-place, but there are no firm rules about how much crime must be found in an area in order to classify it as hot spot. An area labelled as a hot spot has higher criminal activity than other places in the territory considered. ${ }^{36}$ Both the location and stability of the frequency of crimes over time are considered in order to classify a specific area as a hotspot. As Spelman (1995) noted, if hot spots shifted each year, it would make no sense to focus on such areas, because they would become free of crime without any intervention. Hot spot

\footnotetext{
31 Bruinsma and Weisburd, Encyclopedia of Criminology and Criminal Justice, 419; Goldstein, Problem-Oriented Policing. 32 Tilley, 'Modern Approaches to Policing: Community, Problem-Oriented and Intelligence-Led', 382.

33 William Spelman and John E Eck, Problem-Oriented Policing (Washington, D.C.: U.S. Department of Justice, 1987); Bruinsma and Weisburd, Encyclopedia of Criminology and Criminal Justice, 3990-3992.

34 Skogan and Hartnett, Community Policing, Chicago Style; Skogan and Frydl, Fairness and Effectiveness in Policing: The Evidence; Tilley, 'Modern Approaches to Policing: Community, Problem-Oriented and Intelligence-Led'.

35 Bruinsma and Weisburd, Encyclopedia of Criminology and Criminal Justice, 2352; David Weisburd, 'Place-Based Policing', in Ideas in American Policing (Washington, D.C.: Police Foundation, 2008), 1-16.

36 Bruinsma and Weisburd, Encyclopedia of Criminology and Criminal Justice, 2353.
} 
policing includes a range of police responses which focus on areas where criminal activities are concentrated and vary according to crime, context and geographic area. $^{37}$

\section{Intelligence-led policing}

Similarly to community policing, intelligence-led policing has numerous definitions. The main objective of this policing approach is to use intelligence and information technology to support the work of the police. Keywords by author do not show any relevant connection between these models and other policing models. In this sense, it can be viewed as an independent model according to the keywords.

Wardlaw and Boughton (2006) defined intelligence-led policing as a fundamental part of the way law enforcement do business. On the other hand, the authors also mentioned that there is a lack of definition and fundamental concepts around it. ${ }^{38}$ According to Carter (2004), intelligence-led policing is a philosophy of how intelligence fits into the operations of the police. It provides strategic integration of intelligence into the overall mission of the organisation. ${ }^{39}$

The Bureau of Justice Assistance (2009) also describes that intelligence-led policing is a process for systematically collecting, organising, analysing and utilising intelligence to make better decisions. ${ }^{40}$ Ratcliffe $(2008,89)$, an important researcher in the field, describes intelligence-led policing as "a business model and managerial philosophy where data analysis and crime intelligence are pivotal to an objective decision-making framework that facilitates crime and problem reduction, disruption and prevention through both strategic management and effective enforcement strategies that target prolific and serious offenders". ${ }^{41}$

The model focusses on serious and repeat offenders, because targeting the offenders that commit the majority of crime will eventually help police reduce overall crime within their communities. ${ }^{42}$ Intelligence-led policing is a more centralised and objective method of resources allocation and priority triage than community policing. ${ }^{43}$

\footnotetext{
William Spelman, 'Criminal Careers of Public Places', in Crime and Place, ed. by John E Eck and David Weisburd, vol. 4 (Monsey: Criminal Justice Press, 1995), 115-144.

38 Grant Wardlaw and Jennine Boughton, 'Intelligence-Led Policing: The AFP Approach', in Fighting Crime Together: The Challenges of Policing and Security Networks, ed. by Jenny Fleming and Jennifer Wood (Sydney: University of New South Wales Press, 2006), 134.

39 David L Carter, Law Enforcement Intelligence: A Guide for State, Local, and Tribal Law Enforcement Agencies (Washington, D.C.: U.S. Department of Justice, Office of Community Oriented Policing Services, 2004), 4.

40 BJA, Navigating Your Agency's Path to Intelligence-Led Policing (Washington, D.C.: U.S. Department of Justice, 2009), 3-4.

41 Jerry H Ratcliffe, Intelligence-Led Policing (Cullompton: Willan Publishing, 2008), 89.

42 Ibid.

43 Bruinsma and Weisburd, Encyclopedia of Criminology and Criminal Justice, 2576-2577.
} 


\section{Evidence-based policing}

Sherman introduced evidence-based policing in 1998 and stated that "police practices should be based on scientific evidence about what works best" ${ }^{44}$ Evidence-based policing emphasises the use of research, evaluation, analysis and scientific processes in decision-making. In this context, research can include a wide range of initiatives, from evaluations of interventions to analyses of police behaviour, activities and internal management. ${ }^{45}$

Sherman (1998) distinguished two dimensions within research under the evidence-based policing framework: 1 . evaluation of police tactics and strategies in order to enable better decision-making; and 2. analysis of crime problems and internal issues in order to generate and implement knowledge. Law enforcement agencies should employ strategies which are proven in the field and/or in literature when trying to reduce criminal activities, fear and internal problems. ${ }^{46}$

Lum et al. (2012) acknowledge evidence-based policing as a decision-making framework. The authors state that policies and practices should be supported by research evidence, and not blindly determined by it and that it is important to integrate research with practice. Eventually, this would lead to more objective judgements and greater transparency and legitimacy which could drastically improve the relationship between police and citizens. ${ }^{47}$ Evidence-based policing aims to change traditional non-scientific techniques - based on hunches, best guesses, traditions, stereotypes, moral panics and political pressures - for techniques proven to work by research. ${ }^{48}$ The disconnect between evidence and its use in practice can be illustrated with a quote by Weisburd (2008): “The best example of the disconnect between evidence and its use in practice is the general failure of police agencies to regularly adopt hot spots, or place-targeted patrol, despite the strong evidence of the efficacy of this approach for crime and disorder reduction and the clear criminological support for the spatial concentration of crime." ${ }^{9}$

To conduct research, agencies regularly need to access their and other agencies' data, which in turn can eventually lead to better data recording, collection and analysis, in addition to a push to improve the information system behind it. ${ }^{50}$

In the context of evidence-based policing, different policing models can be categorised according to the 3Ts - targeting, testing and tracking. Intelligence-led policing only targets the crime problem or internal issue (complying with the first $\mathrm{T}$ ), while problem-oriented policing not only targets the crime problem or internal

\footnotetext{
Sherman, Evidence-Based Policing.

Bruinsma and Weisburd, Encyclopedia of Criminology and Criminal Justice, 1426-1427.

46 Cynthia Lum, 'Translating Police Research into Practice', Police Foundation 11 (2009), 1-16; Lawrence W Sherman and John E Eck, 'Policing for Crime Prevention', in Evidence-Based Crime Prevention (New York: Springer, 2003), 309-343.

47 Bruinsma and Weisburd, Encyclopedia of Criminology and Criminal Justice, 1428.

48 Ibid. 1428; Lum, 'Translating Police Research into Practice'.

49 Ibid. 1428; Weisburd, 'Place-Based Policing'.

50 Ibid. 1428.
} 
issue, it also tests different types of intervention (complying with the first two Ts). Evidence-based policing complies with the first two Ts and also tracks the implemented solutions, evaluating their effectiveness. According to this approach, evidence-based policing can be viewed as a main policing model, which, differently from other approaches, complies with all 3Ts. ${ }^{51}$

10 per cent of the publications about community policing contain problemoriented policing as keyword.

Keywords by author showed that 10 per cent of the publications about evidencebased policing contain hot spot policing as keyword. This finding corroborates Sherman and Eck's (2002) conclusion that problem-oriented approaches like directed patrols to hot spots, proactive arrests of serious repeat offenders and drunk drivers, arrest of suspects of domestic violence can also be viewed as part of evidence-based policing. ${ }^{52}$

\section{Predictive policing}

The term predictive policing first appeared in the literature and in the policing field in 2008. Predictive policing includes policing strategies which develop and use information and advanced analytics to inform forward-thinking crime prevention. ${ }^{53}$ In this context, the model has the potential to change fundamentally the way in which the police deals with crime and victims by using predictive analytics to forecast where and when the next crime will likely occur. ${ }^{54}$ Uchida (2009) defines predictive policing as a multi-disciplinary, law enforcement based strategy based on predictive analytics, criminological theories (especially environmental criminology), and tactical operations with the goal of reducing crime, increasing management efficiency, and ultimately making communities safer. ${ }^{55}$ Criminological theories are important in predictive policing. These are used to determine the predictor variables when forecasting crime, to establish the unit of analysis, and to specify the algorithm. ${ }^{56}$

Walt et al. (2013) distinguish four goals within methods used in predictive policing: 1. Methods for predicting crime aim to identify areas at increased risk, identifying places and times in which crimes will happen. 2. Methods for predicting offenders aim to identify individuals at risk of offending in the future. 3. Methods for predicting perpetrators' aim to create profiles that accurately match likely offenders

\footnotetext{
Sherman, Evidence-Based Policing.

Sherman and Eck, 'Policing for Crime Prevention'.

Bratton, 'Transcript: Perspectives in Law Enforcement'.

Bruinsma and Weisburd, Encyclopedia of Criminology and Criminal Justice, 3871.

55 Craig D Uchida, A National Discussion on Predictive Policing: Defining Our Terms and Mapping Successful Implementation Strategies (Los Angeles: National Institute of Justice, 2009).

56 Bruinsma and Weisburd, Encyclopedia of Criminology and Criminal Justice, 3873-3874.
} 
with specific past crimes. 4. Methods for predicting victims of crime aim to identify individuals or groups who are likely to become victims of crime in the future. ${ }^{57}$

Pearsall (2010) defines predictive policing as a general term for any crime fighting approach that includes a reliance on information technology, criminology theory, predictive analysis and the use of data. ${ }^{58}$ Wilson et al. (2009) define it as a risk-based assessment, problem solving and crime prevention strategy, which minimises the uncertainties and maximises the expectations. ${ }^{59}$

In addition, predictive policing is based on other policing models like problemoriented and intelligence-led policing. Hot-spot policing directly includes techniques which contain different types of predictive components. ${ }^{60}$ Keywords by author confirm this relationship by showing that approximately 10 per cent of the publications about predictive policing contain hot spot policing as a keyword, too.

\section{The hierarchy of policing models according to keywords by author}

Based on the findings in the previous section, a hierarchy of policing models was created (see Figure 2).

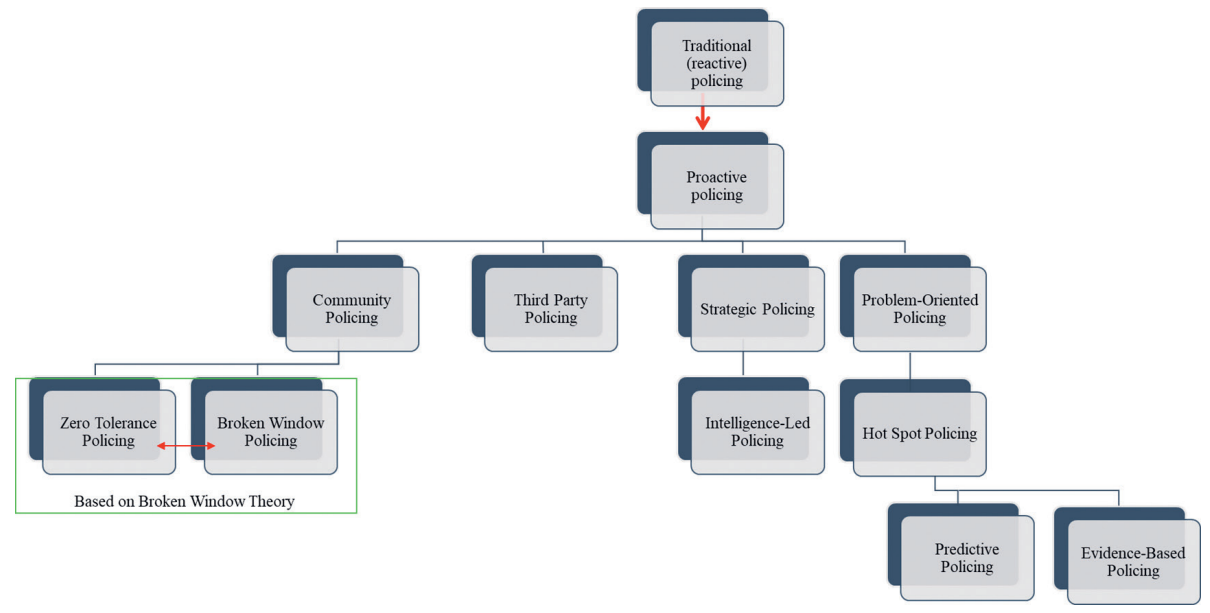

Figure 2: Hierarchy of policing models according to keywords by author.

Source: KeyWord Plus

57 Perry L Walt et al., Predictive Policing: The Role of Crime Forecasting in Law Enforcement Operations (RAND Corporation, 2013), xiv.

58 Beth Pearsall, 'Predictive Policing: The Future of Law Enforcement', National Institute of Justice Journal 266, no 1 (2010), 16-19.

59 Ronald E Wilson et al., Geospatial Technology Working Group Meeting Report on Predictive Policing (Scottsdale: U.S. Department of Justice, 2009).

60 Bruinsma and Weisburd, Encyclopedia of Criminology and Criminal Justice; Uchida, A National Discussion on Predictive Policing: Defining Our Terms and Mapping Successful Implementation Strategies. 
Figure 2 shows the main types of policing models in the literature. Furthermore, it shows that community policing includes zero-tolerance policing and broken windows policing, while problem-oriented policing contains hot spot policing, which is also connected with predictive policing and evidence-based policing. Third-party policing and intelligence-led policing are the only models, which do not connect to other policing models, according to the authors.

As Skogan and Frydl (2004) noted that community policing can have a great impact on reducing criminal activities if it is supplemented with hot spot policing and problem-oriented policing. ${ }^{61}$ It is also worth considering the suggestion of Sherman (1998) about the 3Ts and policing models, where intelligence-led policing represents the first $\mathrm{T}$, while problem-oriented the first two Ts and evidence-based policing all three Ts. ${ }^{62}$

Despite the hierarchy, it is hard to distinguish the different types of policing models from each other - as you can see in this section - because they share similar techniques and approaches, like other authors highlighted it.

\section{Policing model according to keywords generated by KeyWords Plus}

The previous section showed that it is hard to establish the hierarchy of policing models. To understand the connection between policing models, this section aims to represent the relation of policing models based on keywords generated by KeyWords Plus.

For every publication, all the keywords generated by KeyWords Plus were analysed per type of policing model. For each policing model the most used keywords were collected and then the keywords which only appear at one policing model were excluded. The remaining keywords were examined based on how many common keywords they have for each policing model. Table 2 shows the keywords used to establish the relationship between policing models, and the number of how many policing models contain these keywords.

Table 2: Keywords and the number of appearances.

\begin{tabular}{lcc}
\multicolumn{1}{c}{ Keywords } & Number of keywords & Percentage \\
\hline crime & 8 & 88.89 \\
disorder & 5 & 55.56 \\
legitimacy & 4 & 44.44 \\
deterrence & 3 & 33.33 \\
hot-spots & 3 & 33.33 \\
violent crime & 3 & 33.33
\end{tabular}

\footnotetext{
61 Skogan and Frydl, Fairness and Effectiveness in Policing: The Evidence.

62. Sherman, Evidence-Based Policing, 199.
} 


\begin{tabular}{lcc}
\multicolumn{1}{c}{ Keywords } & Number of keywords & Percentage \\
\hline race & 3 & 33.33 \\
city & 2 & 22.22 \\
intelligence & 2 & 22.22 \\
diffusion & 2 & 22.22 \\
displacement & 2 & 22.22 \\
violence & 2 & 22.22 \\
justice & 2 & 22.22 \\
police & 2 & 22.22 \\
community & 2 & 22.22 \\
impact & 2 & 22.22 \\
officers & 2 & 22.22
\end{tabular}

Source: KeyWords Plus

All the policing models contain the keyword crime, except the zero-tolerance policing, which is surprising if you look at the broken windows theory, which is focused on the second most used keyword. The relationship between policing models is outlined in Figure 3, where a strong connection indicates that two policing models share 4 common keywords, in the case of a medium connection, 3 keywords are shared and a weak connection indicates that models share only 2 common keywords. The link analysis shows that third-party policing and problem-oriented policing is strongly connected to community policing, evidence-based policing and hot spot policing. Also, third-party policing and problem-oriented policing can be seen as higher-level policing models, because they have the most number of strong relation, and they are instantly connected to lower level models by a strong relation, like community policing, evidence-based policing and hot spot policing, and indirectly to lower level models, which have only medium connection to other policing models.

Looking at the medium connections, it can be stated that broken windows policing is more connected with evidence-based, hot spot and predictive policing than community and problem-oriented policing. Zero-tolerance and intelligence-led policing only have weak linking with other policing models, and because of that they do not appear in Figure 3.

Between the hierarchy and the link analysis there are some common elements, like the connection between problem-oriented, hot spot and predictive policing, on the other hand, some differences too - like the importance of third-party policing. Third-party policing seems more relevant than other literature suggests it may be. In the future it is worth analysing the importance of third-party policing in the literature. Also, evidence-based policing seems to have more connection to other policing models, than the hierarchy indicates. It proves the point that the hierarchy and the connection between these policing models is more complex than being able to be summarised in one figure. 


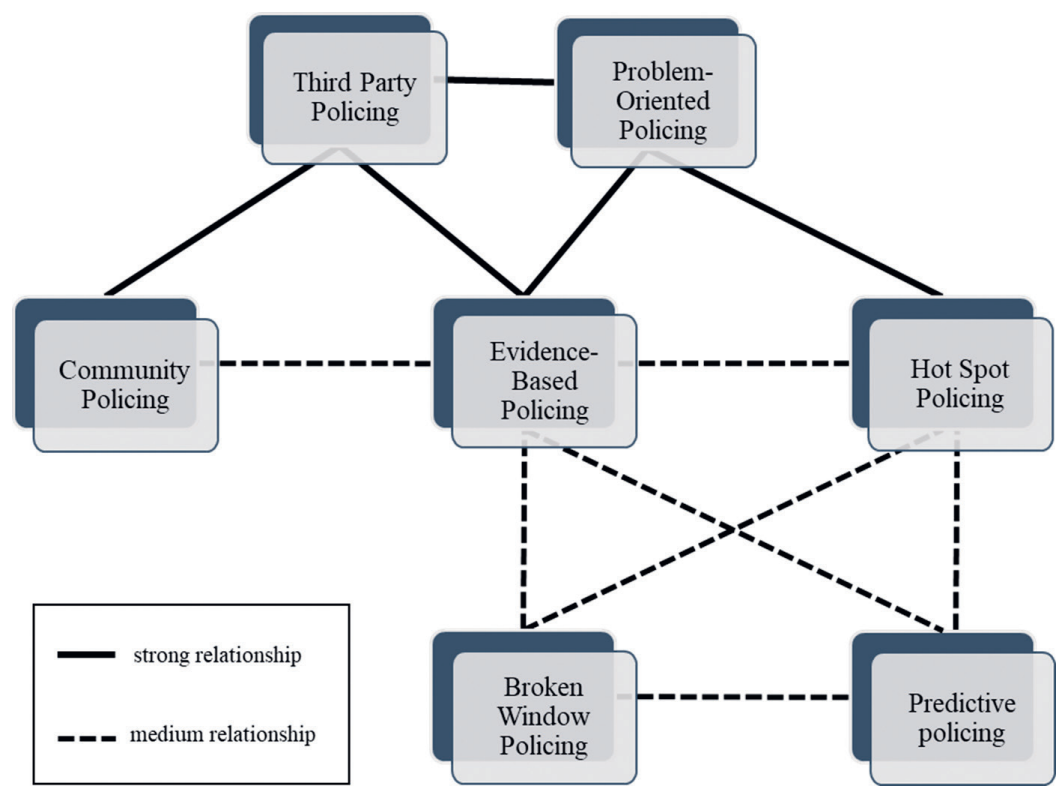

Figure 3: Analysis of the link between different policing models.

Source: KeyWords Plus

\section{Conclusion}

The analysis of the publications focusing on policing models showed that there are three main types of policing models described in the literature currently - community policing, predictive policing and evidence-based policing, the latter of which includes practices which are present in all other policing models. Furthermore, the relationship between the models is complex. This means that articles will usually refer to more than one policing model. The analysis also showed that community policing is still the most relevant policing model in the literature if we look at the number of publications as an indicator of relevancy, and that a significant change happened in the 2010s with publications focusing on evidence-based policing and predictive policing increasing. The relevance of third-party policing is higher according to the second analysis, than the first analysis showed.

As many authors noted that policing models do not exist independently ${ }^{63}$ because of the numerous techniques and approaches.

63 Bruinsma and Weisburd, Encyclopedia of Criminology and Criminal Justice; Sherman, Evidence-Based Policing; Skogan and Frydl, Fairness and Effectiveness in Policing: The Evidence; Tilley, 'Modern Approaches to Policing: Community, Problem-Oriented and Intelligence-Led'. 
The limitation of the study is that it only examined the year of publication and two types of keywords, and did not analyse systematically the relevant articles. It is likely that a more systematic review of article content and model evaluations can be useful to understand and to distinguish the different types of policing models and the contexts in which they may be most effective. This article, however, provides a high-level starting point to understand the connection between the existing policing models.

\section{REFERENCES}

Bayley, David H and Clifford Shearing, 'The Future of Policing'. Law and Society Review 30, no 3 (1996), 585-606. Online: https://doi.org/10.2139/ssrn.2726571

BJA, Navigating Your Agency's Path to Intelligence-Led Policing. Washington, D.C.: U.S. Department of Justice, 2009. Online: https://it.ojp.gov/documents/d/Navigating\%20Your\%20 Agency's\%20Path\%20to\%20Intelligence-Led\%20Policing.pdf

Bratton, William, 'Transcript: Perspectives in Law Enforcement - The Concept of Predictive Policing: An Interview with Chief William Bratton'. Interview by Jim Burch and Kris Rose. Bureau of Justice Assistance, 2008. Online: www.bja.gov/publications/podcasts/multimedia/ transcript/Transcripts_Predictive_508.pdf

Brogden, Michael and Preeti Nijhar, Community Policing: National and International Models and Approaches. Cullompton: Willan Publishing, 2005. Online: www.amazon.co.uk/CommunityPolicing-International-Concepts-Practice/dp/1843920050

Bruinsma, Gerben and David Weisburd (eds), Encyclopedia of Criminology and Criminal Justice. New York: Springer, 2014. Online: https://doi.org/10.1007/978-1-4614-5690-2

Buerger, Michael E and Lorraine Green Mazerolle, 'Third-Party Policing: A Theoretical Analysis of an Emerging Trend'. Justice Quarterly 15, no 2 (1998), 301-327. Online: https://doi. org/10.1080/07418829800093761

Carter, David L, Law Enforcement Intelligence: A Guide for State, Local, and Tribal Law Enforcement Agencies. Washington, D.C.: U.S. Department of Justice, Office of Community Oriented Policing Services, 2004.

Garfield, Eugene, 'KeyWords PIus: 1S1's Breakthrough Retrieval Method. Part 1'. Current Contents 32 (1990), 3-7.

Goldstein, Herman, Problem-Oriented Policing. New York: McGraw-Hill Ryerson, 1990.

Greene, Jack R (ed.), Encyclopedia of Police Science. London: Routledge, 2012.

Kelling, George L and Mark Harrison Moore, 'From Political to Reform to Community: The Evolving Strategy of Police', in Community Policing: Rhetoric or Reality, ed. by Jack R Greene and Stephen D Mastrofski. Westport: Praeger Publishers, 1988, 1-23. Online: www.ncjrs.gov/ App/Publications/abstract.aspx?ID =115736

Kelling, George L and James Q Wilson, 'Broken Windows'. Atlantic Monthly 249, no 3 (1982), 29-38.

Clarivate.com, 'KeyWords Plus Generation, Creation, and Changes', 2019. Online: https://support.clarivate.com/ScientificandAcademicResearch/s/article/KeyWords-Plus-generationcreation-and-changes?language $=$ en_US

Lum, Cynthia, 'Translating Police Research into Practice'. Police Foundation 11 (2009), 1-16. Online: www.policefoundation.org/wp-content/uploads/2015/06/Ideas_Lum_0.pdf

Lum, Cynthia, Cody W Telep, Christopher S Koper and Julie Grieco, 'Receptivity to Research in Policing'. Justice Research and Policy 14, no 1 (2012), 61-95. Online: https://doi.org/10.3818/ JRP.14.1.2012.61 
Pearsall, Beth, 'Predictive Policing: The Future of Law Enforcement'. National Institute of Justice Journal 266, no 1 (2010), 16-19.

Ratcliffe, Jerry H, Intelligence-Led Policing. Cullompton: Willan Publishing, 2008.

Sherman, Lawrence W, Evidence-Based Policing. Washington, D.C.: Police Foundation, 1998.

Sherman, Lawrence W and John E Eck, 'Policing for Crime Prevention', in EvidenceBased Crime Prevention. New York: Springer, 2003, 309-343. Online: https://doi.or$\mathrm{g} / 10.4324 / 9780203166697-13$

Skogan, Wesley G and Kathleen Frydl, Fairness and Effectiveness in Policing: The Evidence. Washington, D.C.: The National Academies Press, 2004. Online: https://doi.org/doi. org/10.17226/10419

Skogan, Wesley G and Susan M Hartnett, Community Policing, Chicago Style. Oxford: Oxford University Press, 1999. Online: www.amazon.com/Community-Policing-Chicago-Studies-Public/ $\mathrm{dp} / 0195105605$

Skolnick, Jerome H and David H Bayley, The New Blue Line: Police Innovation in Six American Cities. New York: Simon and Schuster, 1988.

Spelman, William, 'Criminal Careers of Public Places', in Crime and Place, ed. by John E Eck and David Weisburd, vol. 4. Monsey: Criminal Justice Press, 1995, 115-144. Online: http://citeseerx.ist.psu.edu/viewdoc/download?doi=10.1.1.361.7838\&rep=rep1\&type=pdf

Spelman, William and John E Eck, Problem-Oriented Policing. Washington, D.C.: U.S. Department of Justice, 1987. Online: https://books.google.hu/books?hl=hu\&lr=\&id=8JbaAAAAM AAJ\&oi=fnd\&pg=PP8\&dq=Problem-oriented+policing+1987\&ots=LbNJL6PNH6\&sig=bHpv IqhO-sOjd9sWctjFR91Q8rI\&redir_esc=y\#v=onepage\&q=Problem-oriented\%20policing\%20 1987\&f=false

Tilley, Nick, 'Modern Approaches to Policing: Community, Problem-Oriented and Intelligence-Led', in Handbook of Policing, ed. by Tim Newburn, $1^{\text {st }}$ ed. Cullompton: Willan Publishing, 2003, 373-403.

Trojanowicz, Robert C and Bonnie Bucqueroux, Community Policing: A Contemporary Perspective. Cincinnati: Anderson Publishing Company, 1990.

Uchida, Craig D, A National Discussion on Predictive Policing: Defining Our Terms and Mapping Successful Implementation Strategies. Los Angeles: National Institute of Justice, 2009. Online: www.ncjrs.gov/App/Publications/abstract.aspx?ID =252437

Walt, Perry L, Brian McInnis, Carter C Price, Susan C Smith and John S Hollywood, Predictive Policing: The Role of Crime Forecasting in Law Enforcement Operations. RAND Corporation, 2013. Online: https://doi.org/10.7249/RR233

Wardlaw, Grant and Jennine Boughton, 'Intelligence-Led Policing: The AFP Approach', in Fighting Crime Together: The Challenges of Policing and Security Networks, ed. by Jenny Fleming and Jennifer Wood. Sydney: University of New South Wales Press, 2006, 133-149.

Weisburd, David, 'Place-Based Policing', in Ideas in American Policing. Washington, D.C.: Police Foundation, 2008, 1-16. Online: www.policefoundation.org/publication/place-basedpolicing/

Weisburd, David and John E Eck, 'What Can Police Do to Reduce Crime, Disorder, and Fear?' The Annals of the American Academy of Political and Social Science 593, no 1 (2004), 42-65. Online: https://doi.org/10.1177/0002716203262548

Wilson, Ronald E, Susan C Smith, John D Markovic and James L LeBeau, Geospatial Technology Working Group Meeting Report on Predictive Policing. Scottsdale: U.S. Department of Justice, 2009. Online: www.ncjrs.gov/pdffiles1/nij/237409.pdf

Wright, Richard A and J Mitchell Miller (eds), Encyclopedia of Criminology. New York: Routledge, 2005. Online: https://doi.org/10.4324/9780203942796 